\title{
Concerted overexpression of the genes encoding p21 and cyclin D1 is associated with growth inhibition and differentiation in various carcinomas
}

\author{
J S de Jong, P J van Diest, R J A M Michalides, J P A Baak
}

\begin{abstract}
Aims-To investigate the expression of the genes encoding cyclin D1 and p21 in proliferative and non-proliferative cells, as demonstrated by the Ki67 antibody, and to correlate these findings with differentiation.

Methods-Immunohistochemistry and immunofluorescence double staining were performed on three breast cancers, two squamous cell cancers of the head and neck, and one ovarium cystadenocarcinoma. In addition, the in vitro effect of cyclin D1 on p21 gene expression in MCF7 breast cancer cells was evaluated.

Results-Immunofluorescence double staining showed a differentiation related gradient in the detection of the Ki67 antigen, cyclin D1, and p21 in squamous cell cancers of the head and neck: Ki67 was detected in the basal layers of the tumour and the cyclin D1 and p21 genes were coexpressed in the higher, more differentiated layers of the tumour. The breast and ovarian cancers often had cells that coexpressed the p21 and cyclin D1 genes, whereas coexpression of cyclin $D 1$ and Ki67 did not occur. Western blot analysis of the MCF7 breast cancer cells showed an upregulation of $\mathrm{p} 21$ production when cyclin D1 gene expression was induced.

Conclusion-Overexpression of the cyclin D1 gene seems to lead to growth arrest in a variety of human cancers, possibly through the induction of p21 by cyclin D1. In squamous cell cancer, concerted overexpression of the genes encoding cyclin D1 and p21 might also induce differentiation. (F Clin Pathol: Mol Pathol 1999;52:78-83)
\end{abstract}

Keywords: cyclin D1; p21; proliferation; differentiation

Cell cycle progression in eukaryotes is controlled by a series of proteins named cyclins. At least eight cyclin genes have been identified in mammalian cells. They are classified into three groups: G1 cyclins, an A-type cyclin, and two B-type cyclins. The genes encoding the G1 cyclins, cyclins D1-3 and cyclin E, are expressed maximally during the G1 phase of the cell cycle and regulate the transition of the cell cycle from G1 into the S phase. ${ }^{12}$ Cyclin A is mainly expressed in the late G1 and early $S$ phase and presumably enhances entry into and transition through the S phase. ${ }^{3}$ The B-type cyclins regulate entry into and exit from the mitotic phase. ${ }^{4}$ The cyclins act by binding to and stimulating the activities of a series of proteins named the cyclin dependent kinases (CDKs). At least six CDKs (CDK 1-6) have been identified. ${ }^{5} \mathrm{CDK} 4$ and CDK6 can associate with the D-type cyclins. The CDK4-cyclin D1 complex plays a role in the transition from the G1 to $S$ phase by phosphorylation of the retinoblastoma protein $(\mathrm{pRb})$, thereby releasing the transcription factor E2F. The discovery of CDK kinase inhibitory (CKI) proteins has provided a new paradigm for the control of cell growth, which links the biochemical events surrounding cell cycle arrest with various physiological processes, including the cellular response to DNA damage, response to growth inhibitory signals, suppression of tumorigenesis, senescence, and differentiation. ${ }^{67}$ Two families of CKIs have been described in mammalian cells. The p16 family, also known as the INK4 family (inhibitor of CDK4) can only inhibit CDK4-cyclin D and CDK6-cyclin D complexes. ${ }^{8}$ The other family, the p21 family, which includes $\mathrm{p} 21^{\mathrm{cip} 1 / \text { waf1 }, 9}, \mathrm{p} 27^{\mathrm{kip} 1},{ }^{10}$ and $\mathrm{p} 57^{\mathrm{kip} 2},{ }^{11}$ can inhibit the activity of a variety of CDK-cyclin kinase complexes. p2 $1^{\text {cip1/waf1 }}$ is known to inhibit the kinase activity of the CDK4-cyclin D1 complex. ${ }^{12}$ p21 regulates cyclin-CDK activity by the number of bound p21 molecules: active complexes contain a single p21 molecule, whereas inactive complexes contain multiple p21 molecules. ${ }^{13}$ p21 gene expression can be regulated directly by the p53 tumour suppressor gene: the promoter region of $\mathrm{p} 21$ contains two consensus p53 binding sites. ${ }^{14}$ Introduction of $\mathrm{p} 21$ into malignant cells can result in G1 phase arrest, altered morphology, and cell differentiation. ${ }^{15}$

There is accumulating evidence for a dual role of cyclin D1 in cell cycle control. Cyclin D1 can promote progression through the G1 phase by associating with CDK4, which results in phosphorylation of $\mathrm{pRb}$, thereby releasing $\mathrm{E} 2 \mathrm{~F}$ from the $\mathrm{pRb}-\mathrm{E} 2 \mathrm{~F}$ complex. Different studies showed a shortened G1 phase in mouse fibroblasts, ${ }^{16}$ rat cells, ${ }^{17}$ and breast cancer cells, ${ }^{18}$ as a result of overexpression of the cyclin D1 gene. One study on human breast cancer, however, showed an association between overexpression of the cyclin D1 gene and high telomerase activity without an increase in tumour cell proliferation. ${ }^{19}$ In other studies, cyclin D1 gene overexpression in HBL100 breast tumour cells could prolong the $S$ phase, which resulted in increased expression of
Accepted for publication 26 November 1998 
$\beta$-casein in these cells, ${ }^{20}$ and inhibited DNA replication, ${ }^{21}$ pointing to a growth restricting function for cyclin D1. The latter observations fit well with our previous finding that overexpression of the cyclin D1 gene in invasive breast cancer correlated negatively with proliferation, as expressed by the number of mitotic figures. ${ }^{22}$ In addition to the association between overexpression of the cyclin D1 gene and a low proliferation rate, cyclin D1 seemed to be related to tumour differentiation because well differentiated tumour types more often overexpress the cyclin D1 gene than do poorly differentiated tumours. ${ }^{2-25}$ Alterations of the cyclin D1 gene (also known as PRAD1, bcl-1), located at chromosome $11 \mathrm{q} 13$, leading to increased synthesis of the cyclin D1 protein, have been found in many different tumour types, such as carcinomas of the breast, oesophagus, bladder, liver, and stomach, squamous carcinomas of the head and neck, ${ }^{26-28}$ parathyroid adenomas, ${ }^{29}$ and mantle cell lymphomas. ${ }^{30-32}$ To investigate the association between cyclin D1 and proliferation and differentiation, we examined different tumours for their expression patterns of cyclin D1, p21, and the proliferation associated protein Ki67. In addition, we evaluated the in vitro effect of cyclin D1 on p21 gene expression in MCF7 breast cancer cells.

\section{Material and methods \\ TUMOUR SPECIMENS}

Fresh operation specimens from three invasive breast cancers, two squamous cell cancers of the head and neck, and one ovarium cystadenocarcinoma were cut into slices of $\sim 0.5 \mathrm{~cm}$ thickness. These cancers were selected for their cyclin D1 positivity. Tissues were fixed for at least 24 hours in neutral buffered $10 \%$ formaldehyde. After paraffin wax embedding, $4 \mu \mathrm{m}$ thick sections were cut for routine staining with haematoxylin and eosin, immunohistochemistry, and immunofluorescence.

IMMUNOHISTOCHEMISTRY

For immunohistochemistry, the sections were mounted on 3-aminopropyltriethoxy silane (APES; Sigma, Zayndrecht, The Netherlands) coated slides. An avidin-biotin peroxidase technique was used for staining the cyclin D1, p21, p53, and Ki67 antigens. After the slides were dewaxed, endogenous peroxidase activity was blocked by incubation in $0.3 \%$ ( $\mathrm{vol} / \mathrm{vol}$ ) hydrogen peroxide in methanol for 30 minutes. The slides were heated at $100^{\circ} \mathrm{C}$ in a $0.01 \mathrm{M}$ citrate buffer ( $\mathrm{pH}$ 6.0) for 15 minutes for antigen retrieval. Thereafter, the slides were preincubated with normal rabbit serum $(1 / 20)$ for 10 minutes. Subsequently, the slides were incubated for 16 hours at $4^{\circ} \mathrm{C}$ with mouse monoclonal antibodies against cyclin D1 (clone DCS-6, IgG2a; Novocastra, Newcastle, $\mathrm{UK} ; 1 / 40$ dilution), p21 (clone $6 \mathrm{~B} 6, \mathrm{IgG} 1$; PharMingen, Los Angeles, California, USA; 1/200 dilution), p53 (clone DO-7; Dako, Glostrup, Denmark; 1/500 dilution), and Ki67 (Mib1, IgG1; Immunotech SA, Marseille, France; $1 / 40$ dilution). The slides were then incubated with a biotinylated rabbit antimouse antibody (1/500) for 30 minutes. The slides were subsequently incubated with avidinbiotinyl peroxidase complex (1/200) for one hour. 3,3'-diaminobenzidine tetrahydrochloride (Sigma) was used as a chromogen. Between steps, the slides were rinsed for 10 minutes in phosphate buffered saline (PBS) three times. All sections were lightly counterstained with haematoxylin.

IMMUNOFLUORESCENCE DOUBLE STAINING

For double staining of cyclin D1/Ki67 and cyclin D1/p21, the sections were pretreated as for single staining (see above). Thereafter, sections were preincubated with normal goat serum (1/20) for 10 minutes. Subsequently, sections were incubated with a mixture of cyclin D1 and Mib1 (both antibodies at a dilution of $1 / 40)$ or cyclin D1 and p21 (1/40 and $1 / 200$ dilutions, respectively) for 16 hours at $4^{\circ} \mathrm{C}$. Slides were reacted with isotype specific secondary antibodies by incubation with a mixture of horseradish peroxidase (HRP) labelled goat antimouse IgG2a (1/50 dilution; Southern Biotechnology, Birmingham, USA) and biotin labelled goat antimouse IgG1 (1/50 dilution; Southern Biotechnology) for $30 \mathrm{~min}$ utes. Sections were incubated with fluorescein isothiocyanate (FITC) labelled tyramine (1/10 dilution) for 20 minutes $^{33}$ directed against the goat antimouse IgG2a-HRP, resulting in a green signal for cyclin D1 positive cells. Thereafter, sections were incubated for one hour with streptavidine-Cy3 (1/150 dilution; Jackson, West Grave, USA) directed against the goat antimouse IgG1-biotin, resulting in a red signal for Ki67 and p21 positive cells. Sections were counterstained with 4'6-diamidino-2phenylindol-2. $\mathrm{HCl}$ in Tris, $\mathrm{pH} 7.5$ (DAPI; Partec, Münster, Germany) for two minutes.

IMMUNOFLUORESCENCE MICROSCOPY

For visualising the Cy-3 and FITC immunofluorescence signals a Leica DMRB immunofluorescence microscope was used. A standard Cy-3 filter (Leica filter cube N 2.1) was used for visualising the Cy-3 signal and a standard FITC filter (Leica filter cube L 4) was used for visualising the FITC signal. A DAPI/FITC/ Cy-3 triple filter (Filter 61000; Chroma Technology, Vermont, USA) was used for visualising the Cy-3 (red), FITC (green), and DAPI (blue) signals and the coexpression of $\mathrm{Cy}-3$ and FITC (yellow) in one view.

CELL CULTURE AND INDUCTION OF OVEREXPRESSION OF THE CYCLIN D1 GENE Human epithelial MCF7 breast tumour cells and the cyclin D1 transfected MCF7 clone 3 cells were cultured in Dulbecco's modified Eagle's medium (DMEM) supplemented with $10 \%$ fetal calf serum (FCS), $2 \mathrm{mM}$ glutamine, $100 \mathrm{U} / \mathrm{ml}$ penicillin, and $100 \mu \mathrm{g} / \mathrm{ml}$ streptomycin. The cyclin D1 transfected MCF7 clone 3 cells contained the pUHd15-1 and pSV2 neotetracycline sensitive transactivator, the tetcyclin D1 plasmid, and the thymidine kinasehygromycin plasmid, as described previously. ${ }^{34}$ These cells were cultured in the presence of 10 $\mu \mathrm{g} / \mathrm{ml}$ tetracycline to suppress the production 

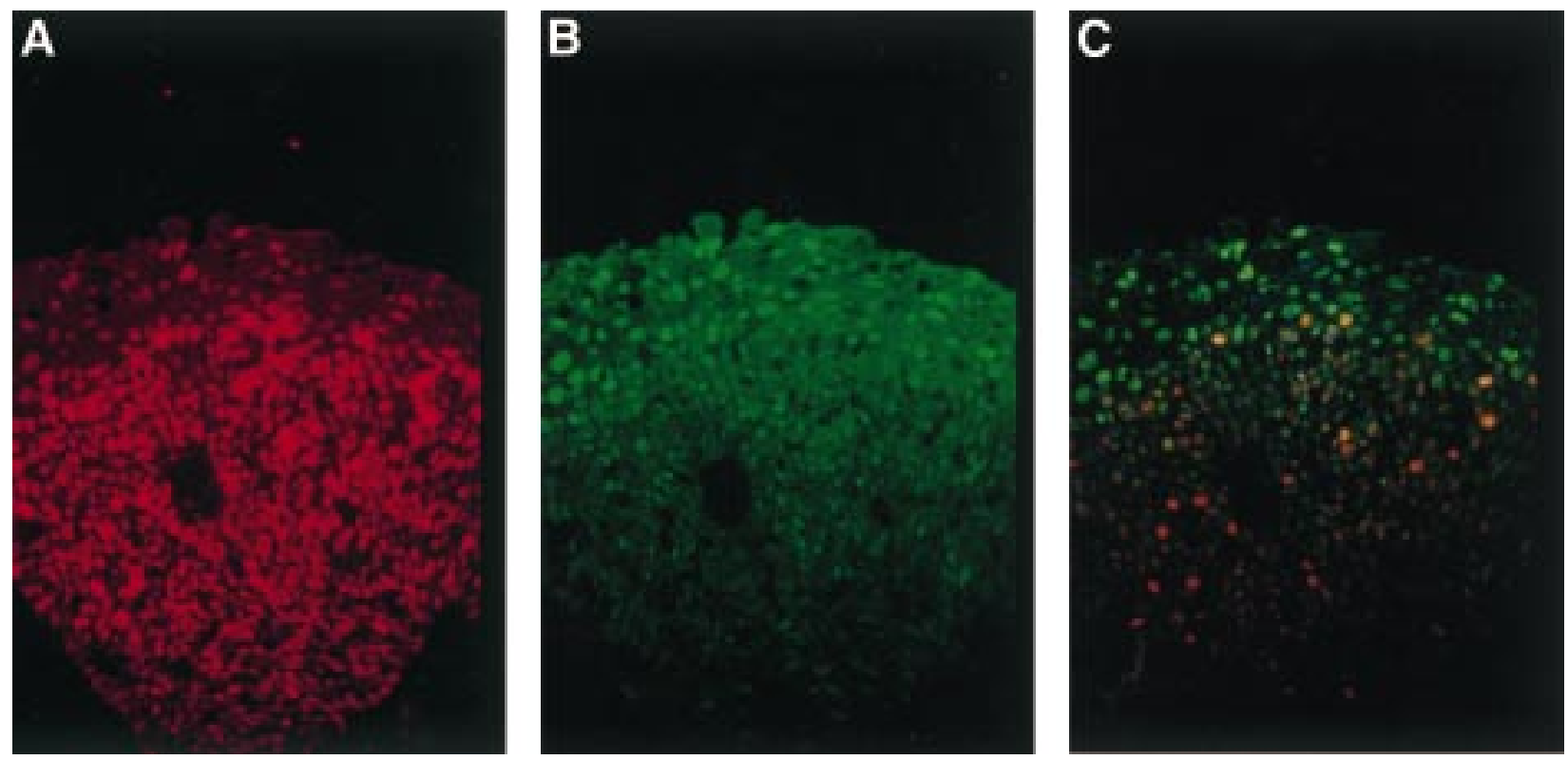

Figure 1 Immunofluorescence staining for cyclin D1 and Ki67 in a squamous cell carcinoma. (A) A gradient is seen for Ki67 positive cells (red), with positive cells being found frequently in the basal layers of the epithelium and few being detected in the higher layers; (B) the opposite is seen for cyclin D1 (green). Faint basal staining is probably attributable to crossover from the blue DAPI staining. (C) In double staining experiments, only very few cells stained for both Ki67 and cyclin D1 (yellow), with low (probably physiological) concentrations of cyclin D1 being detected.

of ectopic cyclin D1, whereas tetracycline was omitted when overproduction of ectopic cyclin D1 was wanted.

WESTERN BLOT ANALYSIS

MCF7 cells were cultured in medium with $10 \%$ FCS for 60 hours in the presence or absence of tetracycline. Total cell extracts were prepared by lysis of cell monolayers with Laemmli sample buffer without bromophenol blue. The protein concentration was measured by the method of Lowry et al..$^{35}$ Equal amounts of protein $(50 \mu \mathrm{g})$ were separated by sodium dodecyl sulphate (SDS) polyacrylamide gel electrophoresis and blotted on to a cellulose nitrate membrane (Schleicher and Schuell).

Immunoblot analysis was performed on different strips of the membrane with an anti-pRb (IF-8; Santa Cruz Biotechnology, Santa Cruz, California, USA), anticyclin D1 (DCS-6; Progen, Newcastle, UK), anti-p21 (187; Santa Cruz Biotechnology), and an antitubulin monoclonal antibody (a kind gift of Dr S Feltkamp, the Netherlands Cancer Institute) as a control. Immunodetection was performed with the enhanced chemiluminescence ECL system (Amersham, Little Chalfont, UK).

\section{Results}

The single stained sections of the different tumour types showed the following results. In squamous cell cancers, $\mathrm{Ki} 67$ was found in the basal layers, whereas cyclin D1 and p21 were seen exclusively in the higher layers of the tumours. Immunofluorescence double staining showed only occasional, low coexpression of cyclin D1 and Ki67 in the basal layers (probably at physiological levels). There was a clear gradient in the detection of cyclin D1, p21, and Ki67. The p21 and cyclin D1 strongly positive cells were located in the higher layers of the tumour, whereas the Ki67 positive cells were in the basal layers of the tumour (fig 1).
Cyclin D1 and p21 genes were coexpressed in many cells (fig 2 ). In addition, cells within the breast and ovarian cancers often coexpressed p21 and cyclin D1, whereas coexpression of cyclin D1 and Ki67 did not occur.

The squamous cell cancers, ovarium cystadenocarcinoma, and one of the breast cancers were positive for $\mathrm{p} 53$. The other two breast cancers did not express p53.

Western blot analysis of the MCF7 breast cancer cells showed an upregulation of p21 when cyclin D1 synthesis was induced (fig 3). Expression of the cyclin D1 gene was induced in MCF7 clone 3 cells by means of the tetracycline regulated transcriptional activation system, ${ }^{36}$ as described previously. ${ }^{34}$ The advantage of using the tetracycline responsive expression system is that results are not influenced by clonal variation. Similar results were obtained with another inducible clone of cyclin D1 in MCF7 clone 8 cells. The concentration of cyclin D1 seen in cells cultured in the presence of tetracycline reflected the endogenous concentration of cyclin D1, whereas omission of tetracycline from the medium resulted in a five to sixfold overproduction of cyclin D1 (fig 3). The extent of phosphorylation of $\mathrm{pRb}$ hardly differed when the cells were cultured in $10 \%$ FCS in the presence or absence of tetracycline. The control, tubulin, showed bands of a similar intensity in the presence and absence of tetracycline. However, p21 production changed drastically in MCF7 clone 3 cells, with overproduction of ectopic cyclin D1 in comparison with cells with a normal concentration of endogenous cyclin D1. The raised p21 concentration in MCF7 clone 3 cells did not result in an altered cell cycle distribution, because we did not see any pronounced differences in the cell cycle distribution of cells overexpressing the cyclin D1 gene compared with those not overexpressing 

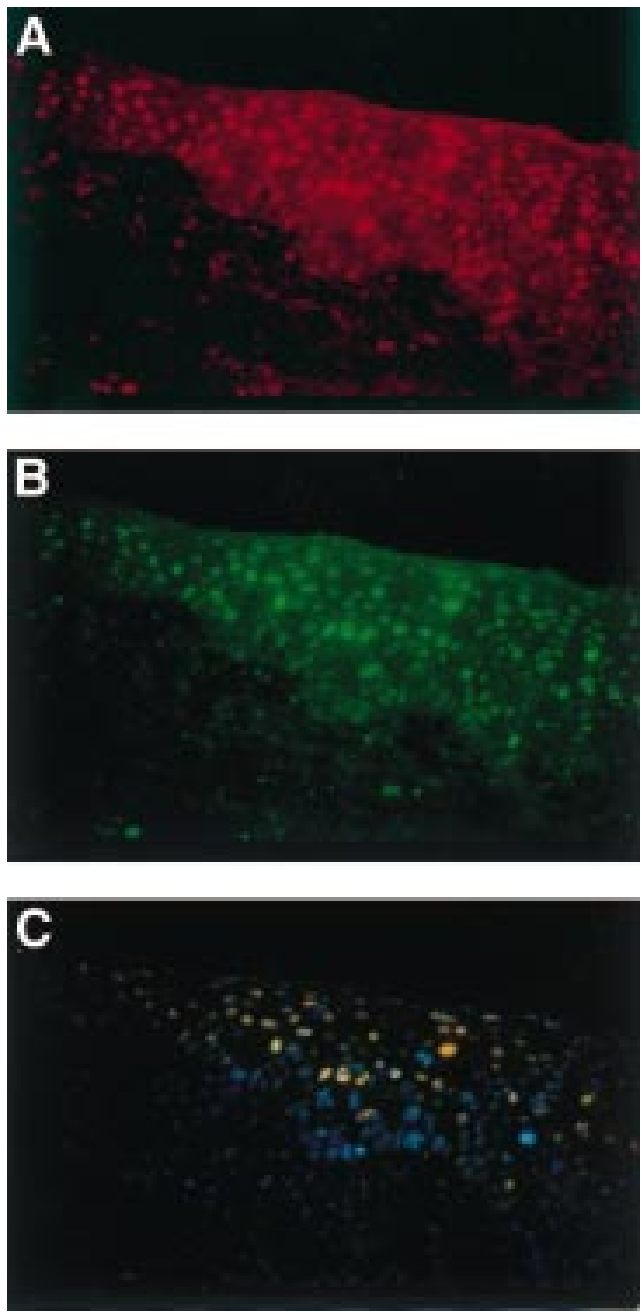

Figure 2 Immunofluorescence double staining of cyclin D1 and p21 in a squamous cell carcinoma. (A) p21 positive cells (red) and (B) cyclin D1 positive cells (green) are seen mainly in the higher, more differentiated layers of the epithelium. Faint basal staining is probably attributable to crossover from the blue DAPI staining. (C) Double staining experiments show that many cells coexpress the cyclin D1 and 21 genes (yellow).

this gene (data not shown), nor in the growth curves between these two types of cell. ${ }^{34}$

\section{Discussion}

In our study, we investigated the expression of the cyclin D1 and p21 genes in proliferative and non-proliferative cells, as demonstrated by the Ki67 antibody. This study was stimulated by the finding in previous studies of invasive breast cancer that cyclin D1 seemed to be associated with decreased proliferation and with enhanced differentiation. ${ }^{22-25}$ These results pointed to a more complex role for cyclin D1 in human tumours than is suggested by other in vitro and in vivo studies, showing that high concentrations of cyclin D1 render cell growth independent of growth factors. ${ }^{34}$ 37-39

In a previous study, we found raised concentrations of cyclin D1 in 59\% of breast carcinomas, as detected by immunohistochemistry. Most of these tumours were well differentiated, characterised by oestrogen receptor positivity, a high degree of tubule formation, small nuclei, and a low proliferation rate, whereas the most

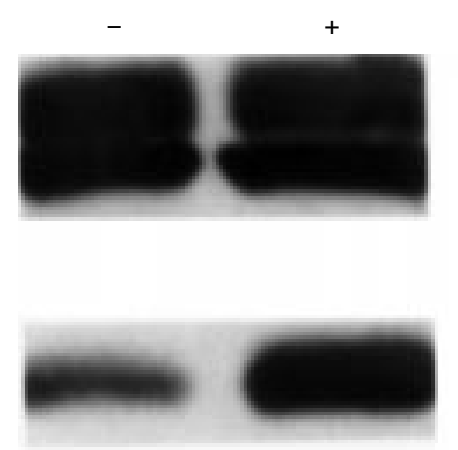

$\mathrm{pRb}$

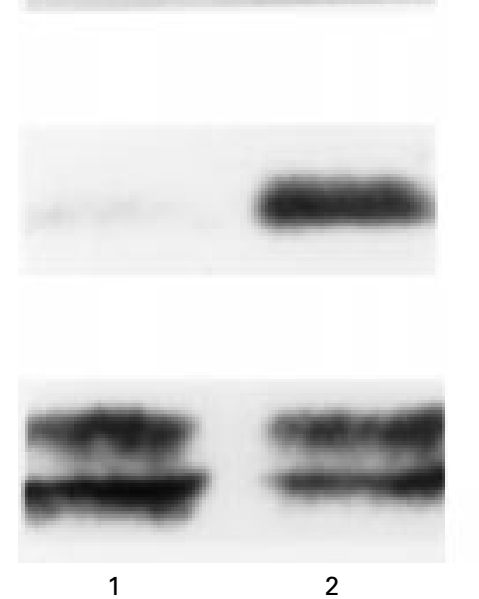

Cyclin D1

p21

Tubulin

Figure 3 Expression of the $p 21$ gene after cyclin D1 induction in MCF7 clone 3 cells. Clone 3 cells were cultured for 60 hours with $(+)$ or without $(-)$ induction of

exogenous cyclin D1 gene expression. Equal amounts of cell lysate were separated on denaturing gels and subjected to western blotting with antibodies against pRb, cyclin D1, $p 21$, and tubulin as described. The broad $p R b$ band indicates the position of hypophosphorylated and hyperphosphorylated $p R b$. Note the upregulation of the $p 21$ gene after induction of cyclin D1.

poorly differentiated tumours of the medullary type, characterised by oestrogen receptor negativity, solid growth, large atypical nuclei, and a high proliferation rate, were consistently cyclin D1 negative. ${ }^{22}$ In our present study, on the single cell level, we found almost no cyclin D1 in proliferating cells as marked by $\mathrm{Ki} 67$ staining. However, we did find a notable coexpression of the cyclin D1 and p21 genes in different tumour types. Furthermore, in squamous cell cancers, we found a gradient through the epithelium in the expression of Ki67, cyclin D1, and p21, whereby the Ki67 positive proliferating cells were localised in the basal layers of the epithelium, and the cyclin D1 and p21 genes were coexpressed in the higher layers of the epithelium. The localisation of cells overexpressing the cyclin D1 gene in higher epithelial layers in squamous cell cancers has been reported by others. ${ }^{40} 41$ Because cells overexpressing the cyclin D1 gene were almost all negative for Ki67 in our study, high cellular concentrations of cyclin D1, as demonstrated by immunohistochemistry, might not be associated with proliferation. Rather, these cells seem to have undergone proliferation arrest. In these cells, high concentrations of cyclin D1 may be related to differentiation, as was shown in squamous cell cancers, where cyclin D1 is produced mostly in the higher, non-proliferating, differentiated 
layers of the epithelium. In the adenocarcinomas, this could not be studied because the differentiation gradient as seen in squamous cell cancers is lacking. This could be more closely studied in raft cultures by transfecting cyclin D1 with a controllable promoter. Nevertheless, breast cancers with many cells overexpressing cyclin D1 are generally well differentiated as described above.

The cell cycle arrest and induction of differentiation in cells overexpressing the cyclin D1 gene might be a result of the induction of $\mathrm{p} 21$. Coexpression of the cyclin D1 and p21 genes was often seen in tumours positive for cyclin D1. In these tumour cells, p21 might cause proliferation arrest, thereby providing the opportunity for cells to differentiate. The involvement of $\mathrm{p} 21$ in the process of differentiation has been shown in different types of cells. ${ }^{42-45}$ The results of the western blot analysis of the MCF7 cells show an upregulation of the $\mathrm{p} 21$ gene after induction of cyclin D1. This result, and the results of others, ${ }^{46}$ indicate that cyclin D1 might upregulate p21 expression. However, the increased concentrations of p21 in cyclin D1 overexpressing cells does not always lead to growth arrest in vitro, ${ }^{34} 46$ although high concentrations of cyclin D1 may be "toxic". ${ }^{16}$ In human cancers, this seems to be different. We suggest that a balance between a positive regulator of the cell cycle, cyclin D1, and a negative regulator, $\mathrm{p} 21$, is generated by a feedback mechanism, where overexpression of the cyclin D1 gene results in induction of $\mathrm{p} 21$. By this mechanism, the effects of overexpression of the cyclin D1 gene might be neutralised, and the resulting proliferation arrest may allow cells to differentiate. How overexpression of the cyclin D1 gene is induced apart from amplification or translocation is as yet unknown, although growth factors have been suggested to play a role. ${ }^{47} \mathrm{pRb}$ deserves attention in this respect because a previous study showed that $\mathrm{pRb}$ stimulated by expression of the $\mathrm{p} 21$ gene may induce cyclin D1. ${ }^{49}$

In the tumours studied there were $\mathrm{p} 21$ positive cells that were cyclin D1 negative. This can be explained by the fact that p21 may also be induced by other proteins such as wild-type p53. However, the ovarian cancer, the two squamous cell cancers, and one of the breast cancers that showed cells with strong coexpression of the p21 and cyclin D1 genes showed strong nuclear staining for $\mathrm{p} 53$, which is highly indicative of a mutation in the p53 gene. Because mutant p53 is not able to induce p21, ${ }^{12} 50$ the described mechanism seems to be independent of $\mathrm{p} 53$. The expression of the $\mathrm{p} 21$ gene might also be upregulated through the mitogen activated protein (MAP) kinase pathway. ${ }^{51}$

Mutually exclusive expression of Ki67 and p21 has also been reported for colonic epithelium. ${ }^{42}$ The accumulation of $\mathrm{p} 21$ in suprabasal layers in squamous cell head and neck cancer was also reported by Erber et $a l^{52}$ and did not coincide with Ki67 positive cells. Remarkably, in that study, overexpression of the p21 gene was reported to be indicative of poor prognosis. Such an association with poor prognosis was also found for overexpression of the cyclin D1 gene in squamous cell head and neck cancers, ${ }^{53} 54$ suggesting that the concerted overproduction of two opposing regulators of the cell cycle, cyclin D1 and p21, may be indicative of poor prognosis in squamous cell cancer of the head and neck. In our study we looked at the single cell level and do not want to speculate about the impact of the described phenomena on the behaviour of tumours.

In conclusion, overexpression of the cyclin D1 gene seems to lead to growth arrest in a variety of human carcinomas, possibly through the induction of $\mathrm{p} 21$ by cyclin D1. In squamous cell cancer, a concerted overexpression of the genes encoding cyclin D1 and p21 might also induce differentiation. However, the exact mechanisms of cyclin D1 overexpression and $\mathrm{p} 21$ induction require further study.

We thank P Kristel for technical assistance in the western blotting experiments and W Vos for technical assistance in the immunohistochemistry experiments. Supported in part by grants 28-2015 and 28-1814 of the Praeventiefonds, and by grant $97-1431$ of the Netherlands Cancer Foundation.

1 Koff A, Giordano A, Desai D, et al. Formation and activation of a cyclin E-cdk2 complex during the G1 phase of the human cell cycle. Science 1992;257:1689-94.

2 Lew DJ, Dulic V, Reed SI. Isolation of three novel human cyclins by rescue of $\mathrm{G} 1$ cyclin (Cln) function in yeast. Cell 1991;66:1197-206.

3 Rosenberg AR, Zindy F, Le Deist F, et al. Overexpression of human cyclin $\mathrm{A}$ advances entry into $\mathrm{S}$ phase. Oncogene 1995;10:1501-9.

4 Nurse P. Universal control mechanism regulating onset of M-phase. Nature 1992;344:503-8.

5 Sherr CJ. Mammalian G1 cyclins. Cell 1993;73:1059-65.

6 Grana X, Reddy EP. Cell cycle control in mammalian cells: role of cyclins, cyclin dependent kinases (CDKs), growth suppressor genes and cyclin-dependent kinase inhibitors (CKIs). Oncogene 1995;11:211-19.

7 Zeng YX, El-Deiry WS. Regulation of $\mathrm{p} 21^{\mathrm{WAF} 1 / \mathrm{CIP} 1}$ expression by p53-independent pathways. Oncogene 1996;12: $1557-64$.

8 Serrano M, Hannon GJ, Beach D. A new regulatory motif in cell-cycle control causing specific inhibition of cyclin D/CDK4. Nature 1993;366:704-7.

9 El-Diery WS, Tokino T, Velculescu VE, et al. WAF1, a potential mediator of p 53 tumor suppression. Cell 1993;75: 817-25.

10 Toyoshima H, Hunter T. p27, a novel inhibitor of G1 cyclin-cdk protein kinase activity, is related to p21. Cell 1994;78:67-74

11 Matsuoka S, Edwards MC, Bai C, et al. p57KIP2, a structurally distinct member of the p21CIP1 Cdk inhibitor family, is a candidate tumor suppressor gene. Genes Dev 1995;9:650-62.

12 El-Diery WS, Harper JW, O'Conner PM,et al. WAF1/CIP1 is induced in p53-mediated G1 arrest and apoptosis. Cancer Res 1994;54:1169-74

13 Zhang H, Hannon GJ, Beach D. p21-containing cyclin kinases exist in both active and inactive states. Genes Dev 1994;8:1750-8.

14 Xiong Y, Hannon GJ, Zhang $\mathrm{H}$, et al. p21 is a universal inhibitor of cyclin kinases. Nature 1993;366:701-4.

15 Yang ZY, Perkins ND, Ohno T, et al. The p21 cyclindependent kinase inhibitor suppresses tumorigenicity in vivo Nat Med 1995;1:1052-6.

16 Quelle DE, Ashmun RA, Shurtleff SA, et al. Overexpression of mouse D-type cyclins accelerates $\mathrm{G} 1$ phase in rodent of mouse D-type cyclins accelerates G
fibroblasts. Genes Dev 1993;7:1559-71.

17 Resnitzky D, Reed SI. Different roles for cyclin D1 and E in Resnitzky D, Reed SI. Different roles for cyclin D1 and E in
regulation of the G1-to-S transition. Mol Cell Biol 1995;15: regulation

18 Musgrove EA, Lee SCL, Buckley MF, et al. Cyclin D1 induction in breast cancer cells shortens $\mathrm{Gl}$ and is sufficient for cells arrested in G1 to complete the cell cycle. Proc Natl Acad Sci USA 1994;91:8022-6.

19 Landberg G, Nielsen NH, Nilsson P, et al. Telomerase activity is associated with cell cycle deregulation in human breast cancer. Cancer Res 1997;57:549-54.

20 Han EK-H, Sgambato A, Jiang W, et al. Stable overexpression of cyclin D1 in a human mammary epithelial cell line prolongs the S-phase and inhibits growth. Oncogene 1995;10:953-61.

21 Pagano M, Theodoras AM, Tam SW, et al. Cyclin D1-mediated inhibition of repair and replicative DNA synthesis in human fibroblasts. Genes Dev 1994;8:1627-39.

22 Diest van PJ, Michalides RJAM, Jannink I, et al. Cyclin D1 expression in invasive breast cancer: correlations and prognostic value. Am ₹ Pathol 1997;150:705-11.

23 Gillett C, Smith P, Gregory W, et al. Cyclin D1 and prognosis in human breast cancer. Int $\mathcal{F}$ Cancer 1996;69:292-9. 
24 Michalides R, Hageman PH, van Tinteren $\mathrm{H}$, et al. A clinico-pathological study on overexpression of cyclin D1 and of p53 in a series of 248 patients with operable breast

cancer. Br $f$ Cancer 1996,73:728-34.

25 Barbareschi M, Pelosio P, Caffo O, et al. Cyclin-D1 gene amplification and expression in breast carcinoma: relation with clinicopathologic characteristics and with retinoblastoma gene product, p53 and p21 WAF1 immunohistochemical expression. Int f Cancer 1997;74:171-4.

26 Lammie GA, Peters G. Chromosome 11q13 abnormalities in human cancer. Cancer Cells 1991;3:413-20.

27 Motokura T, Arnold A. Cyclins and oncogenesis. Biochem Biophys Acta 1993;1155:63-78.

28 Hall M, Peters G. Genetic alterations of cyclins, cyclindependent kinases and $\mathrm{Cdk}$ inhibitors in human cancer. Adv Cancer Res 1996;68:67-108.

29 Motokura T, Bloom T, Kim HG, et al. A novel cyclin encoded by a bcl1-linked candidate ongogene. Nature 1991;350:512-5.

30 Boer de CJ, Krieken JHJM, Nelemans HCK, et al. Cyclin D1 messenger RNA overexpression as a marker for mantle D1 messenger RNA overexpression as a ma

31 Rosenberg CL, Wong E, Petty EM, et al. PRAD1, a candidate BCL-1 oncogene: mapping and expression in centrocytic lymphoma. Proc Natl Acad Sci USA 1991;88: 9638-42.

32 Withers DA, Harvey RC, Faust JB, et al. Characterization of a candidate BCL-1 gene. Mol Cell Biol 1991;11:4846-53.

33 Bobrow MN, Litt GJ. The use of catalyzed reporter deposition as a means of signal amplification in a variety of formats. F Immunol Methods 1992;150:145-9.

34 Zwijssen RM, Klompmakers R, Wientjes EB, et al. Cyclin D1 triggers autonomous growth of breast cancer cells by governing cell cycle exit. Mol Cell Biol 1991:16:2554-60.

35 Lowry OH, Rosebrough NJ, Farr AL, et al. Protein measurement with the folin phenol reagent. F Biol Chem 1995;193:265-75.

36 Gossen M, Bujard H. Tight control of gene expression in mammalian cells by tetracycline-responsive promoters. mammalian cells by tetracycline-respons
Proc Natl Acad Sci USA 1992;89:5547-51.

37 Lukas J, Bartkova J, Bartek J. Convergence of mitogenic signaling cascades from diverse classes of receptors at the cyclin D-cyclin dependent-kinase-pRb-controlled G1 checkpoint. Mol Cell Biol 1996;16:6917-25.

38 Wang TC, Cardiff RD, Zukerberg L, et al. Mammary hyperplasia and carcinoma in MMTV-cyclin D1 transgenic mice. Nature 1994;369:669-71

39 Robles AI, Larcher F, Whalin RB, et al. Expression of cyclin D1 in epithelial tissues of transgenic mice results in epidermal hyperproliferation and severe thymic hyperplasia. Proc Natl Acad Sci USA 1996;93:7634-8.

40 Bartkova J, Lukas J, Müller H, et al. Abnormal patterns of D-type cyclin expression and $\mathrm{G}$ regulation in human head and neck cancer. Cancer Res 1995;55:949-56.
41 Uhlman DL, Adams G, Knapp D, et al. Immunohistochemical staining for markers of future neoplastic progression in the larynx. Cancer Res 1996;56:2199-205.

42 Doglioni C, Pelosio P, Laurino L, et al. p21/WAF1/CIP1 expression in normal mucosa and in adenomas and adenocarcinomas of the colon: its relationship with differentiation. F Pathol 1996;179:248-53.

43 Marchetti A, Doglioni C, Barbareschi M, et al. p21 RNA and protein expression in non-small cell lung carcinomas: evidence of $\mathrm{p} 53$-independent expression and association with tumoral differentiation. Oncogene 1996;12:1319-24.

44 Poluha W, Poluha DK, Chang B, et al. The cyclindependent kinase inhibitor p21 (WAF1) is required for survival of differentiating neuroblastoma cells. Mol Cell Biol 1996;16:1335-41.

45 Tron VA, Tang L, Yong WP, et al. Differentiation-associated overexpression of the cyclin-dependent kinase inhibitor p21waf-1 in human cutaneous squamous cell carcinoma. Am F Pathol 1996;149:1139-46.

46 Hiyama H, Lavarone A, LaBaer J, et al. Regulated ectopic expression of cyclin D1 induces transcriptional activation of the cdk inhibitor p21 gene without altering cell cycle progression. Oncogene 1997;14:2533-42.

47 Winston JT, Pledger WJ. Growth factor regulation of cyclin D1 mRNA expression through protein synthesisdependent and -independent mechanisms. Mol Biol Cell 1993;4:1133-44.

48 Sutherland RL, Hamilton JA, Sweeney KJ, et al. Expression and regulation of cyclin genes in breast cancer. Acta Oncol 1995;34:651-6.

49 Chen X, Bargonnetti J, Prives C. p53, through p21 (WAF1/ CIP1), induces cyclin D1 synthesis. Cancer Res 1995;55: 4257-63.

50 Guillot C, Falette N, Paperin MP, et al. p21(WAF1/CIP1) response to genotoxic agents in wild-type TP53 expressing breast primary tumours. Oncogene 1997;14:45-52.

51 Liu Y, Martindale JL, Gorospe M, et al. Regulation of $\mathrm{p} 21^{\mathrm{WAF} 1 / \mathrm{CIP} 1}$ expression through mitogen-activated protein kinase signaling pathway. Cancer Res 1996;56:31-5.

52 Erber R, Klein W, Andl T, et al. Aberrant p21 $1^{\text {CIPINAF1 }}$ protein accumulation in head-and-neck cancer. Int $\mathcal{f}$ Cancer 1997; 74:383-9.

53 Michalides R, van Veelen N, Hart A, et al. Overexpression of cyclin D1 correlates with recurrence in a group of forty-seven operable squamous cell carcinomas of the head and neck. Cancer Res 1995;55:975-8.

54 Michalides R, van Veelen N, Kristel P, et al. Overexpression of cyclin D1 indicates a poor prognosis in squamous cell carcinoma of the head and neck. Arch Otolaryngol 1997;123:497-502. 